\title{
Creation Style and Artistic Features of Verdi’s Operas
}

\author{
Ni Ma \\ Xi'an Shiyou University, Xi'an Shaanxi, 710065, China
}

Keywords: Verdi; opera; creation style

\begin{abstract}
This paper aims to introduce and discuss Verdi's opera creations and features of the Overture. The paper gives a detailed analysis of Verdi's life, his opera creations and cultural trends, social and political background of his creations, also gives an introduction of overall creation features of Verdi's opera in the early, middle and late historical stages.
\end{abstract}

\section{Introduction}

Verdi is good at using beautiful and moving melodies to portray characters with distinct and unique personalities, and further revealing the delicate and complex spiritual world of the characters through these images, finally using image features to promote the further development of the plot.

\section{Overview of Verdi and His Opera Creation}

Verdi's operas were created in the latter part of the 19th century, becoming the main content of Italian opera history and music history at that time. The creations pursue a unique feature in creation technique, concept and aesthetic appreciation which reflect the local characteristics and struggle against the aggressors from form to content. The Italian opera embraced a brilliant and perfect development due to Verdi.

\subsection{Life of Verdi}

Giuseppe Verdi was born into an ordinary family in Ronkoller village in Busseto, Parma province, Italy, and his father, Carlo Verdi, was the owner of a small restaurant in the village. The life was tough and financially-embarrassed. When he was young, Verdi came into contact with the performance of the organ pipe in the village chapel and the music of the wandering artist. When he was ten years old, he attended liberal art school in Busseto and played the organ in church during his spare time. Later, a music-loving businessman Antonio Barezzi discovered Verdi's music talent and actively supported him to learn music. In 1836, He complete his first opera Rochester by self-study, at the same year he married Margherita Barlez. Unfortunately, during the next two years, Verdi suffered terribly because of successively death of his wife and children. In such a grief, he created comic opera Un Giorno di Regno, but received little response. What helped him regain his confidence was the performance of his work Nabocco in 1842, which made him rise to fame. In January 1901, Verdi died at the age of 88. The whole nation was blanketed with grief for his death. People spontaneously flooded to the streets to join the chorus of Va, Pensiero, sull'ali dorate to make a farewell to this king of opera and also the greatest master of opera.

Verdi has created 26 operas in his whole lifetime. His works are skillful and the characters are meticulously depicted. He vividly portrayed human's desires, characters and inner world, with a strong moving power. At the same time, the Italian folk music was integrated everywhere in his works.

\subsection{Social background of Verdi's opera}

To explore the Verdi's opera art, the author thinks that the first step is to understand and be familiar with his social and historical background. Verdi lived in an age when the Italian people were struggling against the rule of Austria, the time when the people of Italy tirelessly fought for the 
reunification of the country, thus making Verdi's creations strikingly marked with the stamps of the times. From the end of the 18th century to the early 19th century, politically, Italy has long been under dual oppression at home and abroad, the internal and international struggles have continued without any interruption. Therefore, the domestic environment is unstable, and Italians yearn for the democratic unity of the country. The young Verdi was brought up in such a period and environment. It can be said that the most of Verdi's life was closely related to the Italian national liberation movement.

\section{Overview and Characteristics of Verdi's Opera Creations}

Verdi won his place in the opera music with his own efforts and talent. He wrote 26 operas throughout his life which represented the highest accomplishment in his composition field. He dedicated all his life to the opera creation and reform, and pushed Italian opera to an unprecedented height.

\subsection{Early stage creations}

Verdi's opera creations in this period mainly refer to the works in 1940s. Many works were related to social politics during this period. Most of the works demonstrate the story and spirit of fighting with power politics, oppression and despotism, and the selection of themes was related to drama literature. The decade from 1839 to 1849 witnessed more than a dozen Verdi's operas. The first opera was Oberto,Conte di San Bonifacio performed at the La Scala Opera and other main works are Nabucco (1842), I Lombardi (1843), Ernani (1844), I due Foscari (1844), Orion (1845), Alzira (1845), Attila (1846), Macbeth (1847), I masnadieri (1847), La battaglia di Legnano (1849), Luisa Miller (1849) and so on, the themes involve the literary works of the Bible, Byron, Hugo, Schiller and other writers. The creation of these works preliminarily established Verdi's position in the music circles. The first opera, Oberto,Conte di San Bonifacio, can be seen as the first work to enter into the gate of Italian opera. And the Italian nationalist sentiment-themed Nabucco (1842) not only arouse a strong social response, but also made Verdi leap into first-class opera composer in Italy, it also objectively stimulated and awakened the Italian patriotic enthusiasm, and generally caused the common people's psychological resonance at that time. In particular, the chorus Va, Pensiero, sull'ali dorate in Nabucco became one of the most classical chorus in European opera art. It has also become a repertoire for many opera and singer concerts in the world, with extremely high artistic and aesthetic values.

To sum up, the content of Verdi's early creations mainly involves a spirit of struggle, revolution and revolt. The story full of twist and turns, with intense feelings and even violent and bloody scenes. The works has inspiring morale and power to encourage and call for everyone to stand up against foreign aggression and oppression and to strive for the freedom and national liberation. In terms of art, the music in Nabucco has not yet matured which lacks the vivid portray of characters and dramatic plots. The characters of the heroes in the play are not prominent and the status of the orchestra is attached to the voice of the human.

\subsection{Metaphase creations}

In the fifties and sixties of the 19th century, Verdi's opera creation reached its peak. The works of this period mainly include Stiffelio (1850, revised Aroldo), Rigoletto (1851, written by Hugo's Le Roi S'Amuse), Il trovatore (1853), La Traviata (1853), Les vêpres siciliennes (1855), Simon Boccanegra (1857) and Un ballo in maschera (1859), etc. Themes are mainly heroes and history, the content involves the common people, reflect the people's oppression and reveal the ugliness of the exploiters and autocrats, and also express sympathy for the people and Italian's democratic aspirations and hatred to the exploiters, provoking passion towards aggressions.

These works mainly have the following characteristics: First, the fast creation speed. The creation of La Traviata has only spent one month, and the creation of Rigoletto has taken 40 days. Second, the focus of Verdi's creative themes in this period turned to the attention to real life, clearly showing the 
change of Verdi's creative ideas. It focuses on the depiction of ordinary people's nature and social ethics instead of grand revolution and fight. Through the opera, he profoundly elaborated the joys and sorrows of the secular world. Especially the realistic, distinct and typical depict of characters' personalities and psychologies makes a close link between character and plot, aria and plot. By using music to advance the further development of dramatic plot, it can make the relation of music and drama more organic and more flexible.

\subsection{Late period creations}

The late period creation was from the 1870s to his death. At this stage, although at an advanced age, Verdi completed his greatest lyrical tragedy Othello and the greatest comedy Falstaff with amazing energy. In these two operas, he combined the drama with melody of opera, and applied the principle of dominant motivation to form a coherence of the plot. This series of dominant motivations are structural integrity, strong melodic and distinctive Image, which play an important role in the portray of characters and the development of the entire drama. Especially in Othello, he integrated the recitative and aria to form a monologue featured with melody and language expression. The "field" writing method carried out the dramatic development represents obvious characteristics in this opera. The work retains the framework of the Italian opera tradition without plot interruption. Through subtle transitions and connections, malleable melodies, bands, and clearly description of characters through bands, thus achieving the continuity of the entire opera. The two operas emphasize the dramatic power of people, and music plays a role of support, fusion and sublimation.

On the structure and overture of the orchestra, Italian composers often used short overture with atmosphere to replace the long overture from the middle of the 19th century. Most operas consist of four acts or three acts plus an overture, each with two or more impressive arias and duets.

Deeply influenced by the Italian literary thoughts, Verdi believed that a musician must not be created for the individual, but should concern the social reality. The composer must produce thoughtful, authenticity and artistry works to reveal social reality and gain the recognition of people. All his works have propelled gloomy Italian opera art to a highly prosperous renaissance of realism. He also received the reputation of "a national hero who fully expresses the Italian spirit with a perfect song." He also correctly and objectively reflected the plot of the story and the emotions of the characters through a proper voice. He often impressed the audience with the beautiful melody singing and the most natural voice to come close to the audiences' lives, so he was also called the "civilian opera composer” because of this affinity and appeal.

In Short, Verdi's opera creations have the following characteristics:

\subsubsection{The intergrowth of music and drama}

In Verdi's creation concept, music is a passionate expression of drama. As mentioned above, he is good at using beautiful and moving melodies to portray characters with distinct and unique personalities, and further revealing the delicate and complex spiritual world of the characters through these images, finally using image features to promote the further development of the plot. Among Verdi's operas, music is often meticulously portrayed with its strong influence on the character image of the play, such as the promotion of the music to the story, the depiction of character's psychology, the conflicts of the characters, etc.

\subsubsection{The distinct and unique characters}

In Verdi's works, especially in mature works, there is a significant feature that characters in the opera are distinctive and rich in emotional world. For example, Ligo Leto in Rigoletto, Azuchinna in Il trovatore and Violetta in La Traviata are all distinct and unique, which leave a deep impression on people. This is an important embodiment of Verdi's opera concept, and he also advocates expressing the universal feelings of the people in the real world, pursuing the opera of human nature, highlighting the care of human nature, and praising the vivid and real people in reality instead of the early political struggle. Therefore, in his works, these characters with conflicts and complicated inner 
world can express the true inner feelings, achieving better drama effects and are more likely to arouse the sympathy of the audience.

\subsubsection{Beautiful and rich musical melody}

Verdi never give up Italian tradition, but has been inheriting, developing and reforming. He attaches great importance to the melody of music. He always adheres to the principle of "singing" of music on the basis of absorbing and learning from the advantages of his predecessors such as Bellini. At the same time, he fully utilizes and absorbs the essence and characteristics of folk music and applied colorful folk songs and dance music elements to his own creations. When absorbing local music elements, he does not forget to absorb the musical languages of Spanish and French nationalities for creative use.

\section{Summary}

He created beautiful and rich musical scores, embodied a clear and simple melody style, and organically combined with strong drama effect, creating eternal classics in opera history. For example, the classic arias La Danna é Mobile and Caro Name in Rigoletto, and Libiamo ne' lieti calici in La Traviata are widely-known and enduring, thus helping Verdi win a reputation of "master of drama" and a "master of opera".

\section{References}

[1] Paul Robinson, Translated by Zhou Binbin, Revised by Yang Yandi, Opera and Ideas-From Mozart to Strauss, East China Normal University Press.

[2] Joseph Coleman, Translated by Yang Yandi, Opera as a Drama, Shanghai: Shanghai Music.

[3] Paul Henry Lang, Translated by Gu Lianli, Zhang Hongdao, Yang Yandi, Revised by Yang Yandi, Music in Western Civilization, Guiyang: Guizhou People’s Press, 2009.

[4] Shen Xuan, Gu Wenxian, Tao Xin. Western Music History Compendium,Shanghai: Shanghai Music Publishing House, 1999. 